\title{
ВЛИЯНИЕ ЦИФРОВИЗАЦИИ ЭКОНОМИКИ НА РЕГУЛИРОВАНИЕ ФИНАНСОВОГО РЫНКА
}

\author{
Цакаев A.X., \\ Саидов 3.A. \\ ФГБОУ ВО «Чеченский государственный университет», \\ г. Грозный, Россия
}

Раскрыта суть иентрачилизации и децентрализаџии регуляторных $и$ надзорных полномочий в сфере финансовой экономики суверенного государства. Показано, что в условиях усиления внешних шоков государство может и обязано предпринимать адекватные меры, в том числе в направлении усиления централизации государственного регулирования национальной экономики и её сегментов - начионального финансового рынка. Выделены и описаны три внешних шоков для российского финансового рынка: коронавирусная пандемия, криптовалютная реальность, торговые войнь и санкции других стран. Обосновано позитивное влияние циифровизации экономических отномений на централизаџию регулирования наџионального финансового рынка в условиях внешних шоков.

Ключевые слова: регулирование, финансовый рынок, коронавирусная пандемия, цифровые деньги, международные санкции и торговые войны.

Современная человеческая жизнь существенно отличается от прошлой. И прежде всего тем, что она стала более динамичной и подверженной частым, порой критичным изменениям как в общественной сфере, так и в личной. Наблюдаемая цифровизация социально-экономических отношений вызвана действие совокупности условий, в числе которых особое место занимают внешние шоки, такие как: коронавирусная атака; криптовалютная экспансия; международные санкции и торговые воины. Это сказывается и на регулировании национального финансового рынка. Именно это и обусловило рассмотрение этих шоков в качестве необходимых условий оцифровки процесса регулирования национального финансового рынка.

Пропорциональное регулирование финансового рынка в современной России осуществляется в соответствии с концептуальными подходами, изложенные в правовых актах $[1,2]$. Но доминирование централизации или децентрализации в регулировании зависит от многих факторов, и прежде всего, как от метода управления (в функции регулирования) финансовых отношений в стране, так и от типа государственного устройства страны. 
Влияние режима управления и типа государственного устройства в стране на централизацию и децентрализацию регулирования и надзора деятельности финансовых организаций специфично. Так, в странах с унитарным государственным устройством наблюдается горизонтальная централизация или децентрализация - либо в сторону объединения государственных институтов государственного управления и регулирования финансовых отношений в стране, либо в сторону выделения (дифференциации) новых институтов государственного управления и регулирования финансовых отношений по мере развития в стране гражданского общества. При этом, внутри объединенного института государственного управления и регулирования наблюдается вертикальная централизация или децентрализация. Но это уже происходит в зависимости от токсичности для страны внешней среды - усиления и ослабления внешних шоков на национальный финансовый рынок и финансовую экономику страны в целом.

В странах с федеративным государственным устройством наблюдается как горизонтальная, так и вертикальная централизация/децентрализация управления и регулирования финансовых отношений в стране - либо в сторону передачи регуляторных и надзорных полномочий на более высокий уровень власти в стране (от муниципального к региональному и от регионального к федеральному). Следует отметить, процессы горизонтальной и вертикальной централизации или децентрализации происходят одновременно в зависимости от развития в стране гражданского общества и степени опасности для страны внешних шоков.

Необходимо выделять субъект и объект регулирования национального финансового рынка. $\mathrm{K}$ субъекту относятся органы государственного регулирования, наделенные регуляторными и надзорными полномочиями, а к объекту - кредитные и другие финансовые организации, осуществляющие предпринимательскую деятельность в различных секторах финансового рынка.

Система управления экономикой в современной России (базирующая на Конституции РФ и других российских законах) является сложным комплексом иерархически связанных между собой государственных и общественных институтов, осуществляющих взаимодействие, как по вертикали, так и на горизонтальном уровне. Так, в современной России и в других странах СНГ (например, Белоруссии) мы наблюдаем режим управления «в ручном режиме» страной, её регионами и муниципальными образованиями. А в США, Германии и других странах наблюдается управление социально-экономическими процессами, основанное преимущественно на методе «управления в автоматическом режиме».

В части субъекта регулирования национального финансового рынка централизация приводит к сокращению их количества вплоть до образования единого, мегарегулятора - в таких странах реализуется модель интегрированного надзора за финансовым сектором страны. В этом случае организация регулирования и надзора за всеми участниками финансового сектора, а также инфраструктурными организациями финансового рынка 
осуществляется в рамках единого государственного органа [3]. Первые мегарегуляторы появились в Норвегии и Сингапуре [4], а институт мегарегулятора по состоянию на 2016 г. существует уже в 60 странах мира [5]. Децентрализация, наоборот приводит к многообразию этих субъектов (государственных органов регулирования финансового сектора страны), в зависимости от типа государственного устройства (унитарный или федеративный).

Проведенный анализ регулирования деятельности российских кредитных и других финансовых организаций, а также движения капитала финансового рынка в России, результаты которого опубликованы в [6], позволил констатировать, во-первых, усиление централизации регуляторных и надзорных полномочий - в руках Банка России. А во-вторых, значительную концентрацию капитала российского финансового рынка в столичном регионе (Москва и Санкт-Петербург). В связи с этим возникает вопрос: почему и чем это вызвано?!

Сегодня российский финансовый рынок - это периферия глобального финансового рынка. В условиях глобальной цифровизации экономических отношений, прежде всего, на цифру переводятся финансово-кредитные отношения - все валютные, фондовые и иные финансовые операции на биржевых площадках осуществляются роботами и цифровыми системами. А сами программы этих систем так запланированы, что, когда наблюдается ухудшение экономической конъюнктуры - капитал устремляется в финансовые центры (Нью-Йорк, Лондон, Токио и пр.). Москва, к сожалению, так и не стала мировым финансовым центром, она остается быть финансовой периферией. Поэтому России, как и другим странам периферии глобальных финансов, приходится нести наибольший ущерб (потери) от оттока капитала. Так было в период мирового финансово-экономического кризиса 2008-2009 гг., такая же картина наблюдается и в 2020 году.

Единственным средством противодействия такому положению является централизация регулирования всей финансовой экономики, включающей финансовый рынок и публичные финансы, и концентрация национального финансово-кредитного капитала в двух мегаполюсах страны - Москве и СанктПетербурге. Видимо, этим и объясняется:

- создание в России 1 сентября 2013 года мегарегулятора финансового рынка в лице Банка России, на основе передачи функций ФССН, ФСФР и др. федеральных служб;

- централизация полномочий в Казначействе России по управлению публичными финансами, на основе ликвидации ФСФБН и др., с существенным сужением полномочий финансовых институтов субъектов РФ и муниципальных образований.

Важным отметить, что влияние цифровизации на российский финансовый рынок, обусловлено сформулированных нами в начале статьи внешних шоков.

1. Коронавирусная атака на финансовый рынок России. Сложившаяся макроэкономическая ситуации в России на начало проявления 
ситуации с коронавирусом, как высказался 26 марта президент России Владимир Путин в ходе выступления на экстренном саммите G 20, «обернется более серьезными проблемами» [7] чем финансовый кризис 2008-2009 годов.

Следует отметить слова главы Международного валютного фонда Кристалины Георгиевой о том, что «Сейчас всем ясно, что мы вошли в рецессию, такую же ужасную или даже хуже, чем в 2009 году» [8]. Еще ранее в МВФ заявляли, что ожидают в 2020 году из-за COVID-19 рецессию в мировой экономике [9].

Во Всемирной организации здравоохранении 3 апреля 2020 г. заявили, что число зараженных коронавирусной инфекцией в мире «превысило 1 млн. чел.», а более 50 тыс. больных скончалось [10].

Безусловно, коронавирусная пандемия является серьезным внешним шоком для российской экономики, её финансового сектора, и российского финансового рынка в частности. И в этой связи представляется не достаточным создания в России антикризисного фонда в 300 млрд рублей для поддержания отраслей экономики и граждан на ситуации с коронавирусом, на фоне мер, принимаемых в США, Китае и других крупных экономиках мира. На финансовом рынке России нерезиденты и примкнувшие к ним резиденты активно избавляются от вложений российский рубль и рублевые активы, тогда как Банк России увеличивает объемы продаж иностранной валюты. На протяжении всего апреля Банк России проводит валютные интервенции с целью поддержать текущий курс рубля, что уже является отходом от политики плавающего курса. Видимо в повестке дня: объявление валютного коридор и ужесточение валютного регулирования в стране на период коронавирусной пандемии. Такова цена коронавирусной пандемии как внешнего шока для российского финансового рынка.

2. Криптовалютная экспансия на российский рынок капитала. Паутина интернета окружила земной шар еще одной жизненно важной оболочкой - планета Земля, как большой мозг, за секунду обменивается информацией, открытиями, знаниями, товарами, деньгами.

В Интернете доступно множество электронных бирж, которые предлагают купить или продать как токены (цифровые сертификаты, которые можно уподобить акциям на традиционном финансовом рынке) различных проектов, так и сами криптовалюты, как, например, биткойн (Bitcoin) или эфириум (Ethereum). А первой страной в СНГ, руководство которой заинтересовалось развитием blockchain и созданием новой цифровой валюты, был Казахстан.

Если раньше в ряде стран биткойн (электронная платежная система, использующая одноименную цифровую валюту) даже был запрещён, и его использование преследовалось по уголовным статьям, то сейчас власти разрешают и поощряют криптовалюты на самом, что ни на есть, официальном уровне.

В России уже громко объявили об интересе к криптовалютам - президент Владимир Путин поручил крупнейшим российским технологическим 
компаниям быстрее создать подразделения для работы со стартапами и инновационными проектами: «Обращаюсь к руководству наших крупнейших компаний - Ростеха, Роскосмоса, Объединенной авиастроительной корпорации, Объединенной судостроительной корпорации, Росатома, других отечественных высокотехнологичных компаний: активно используйте открывающиеся возможности, нужно создать у себя подразделения, которые будут предметно работать со стартапами и малыми инновационными компаниями, а также венчурные фонды, чтобы финансировать такие проекты» [11].

И настоящей сенсацией для криптовалютных рынков стала личная встреча президента России Владимира Путина на Петербургском экономическом форуме в начале июня 2017 года с Виталиком Бутериным, выходцем из России и разработчиком эфириума - второй в мире по популярности (после биткойна) криптовалюты.

Безусловно, развитие цифровой экономики в России есть необходимые предпосылки, а их дальнейшее развитие внесет структурные изменения в различных её областях. Но появление новых платежных средств на основе цифровой технологии Blockchain, как Bitcoin и масcа быстрораспространяющихся альткоинов, создают проблемы для борьбы с отмыванием денег, уходом от налогообложения и другими незаконными действиями, тем самым делая, с одной стороны, эти активы привлекательными, a c другой - делая их потенциально опасными, токсичными для российской экономики. Криптовалюты уже используются для торговли незаконными наркотическими средствами, огнестрельным оружием, иными незаконными товарами, услугами и действиями [12].

3. Международные санкции и торговые войны. Последнее представляет собой торговое соперничество в захвате внешних рынков двух или более государств, и эта торговая война сегодня проводится в рамках экономической войны. Так, на последнем экстренном саммите «Группы 20» от 26 марта 2020 г. Путин В.В., который проходил в формате видеоконференции, отметил, что «... торговые воины и санкции усугубляют рецессию» [13].

Торговые войны нередко перерастают в вооруженные конфликты, особенно в случае попыток прорвать торговую блокаду, переросшее в экономическую блокаду. И напрашивается пример из нашей советской истории сто летней давности - Правительство США прекратило торговые отношения с Советской Россией в конце 1917 года, на следующий год за ним последовали Англия и Франция: полное запрещение экономических связей было объявлено Верховным советом Антанты в октябре 1919 года. Но государства Антанты были вынуждены снять торговую блокаду в январе 1920 года в связи с ущербом своим экономикам. Есть и другие примеры - блокада Кубы и т.д.

Торговые войны сегодня ведутся по тем товарным секторам, которые особенно чувствительны для российской экономики. Так, в нефтегазовом секторе - последние события «конфликта» в рамках ОПЕК+ тому яркое свидетельство - так, по состоянию на 22 апреля 2020 г. цена сырья марки Brent опускалась ниже $\$ 16$, и это самое сильное снижение в текущем столетии [14]; 
В финансово-кредитной сфере - введение санкций против России весной 2014 года, где Крым и Севастополь - это лишь повод для объявления «финансовой» блокады, которая сегодня переросла в «финансовую» войну с Россией - ПАО «Сбербанк России» до сих пор не имеет филиальную сеть в Республике Крым и в г. Севастополь. Будем надеяться, что «покупка Правительством РФ 50\% плюс 1 акция ПАО «Сбербанк России» [15], то есть контрольного пакета у Банка России, позволит изменить кредитную политику самого крупного коммерческого банка в России.

Последствием финансово-экономического кризиса для любой (развитой и развивающейся) экономики является рост безработицы в ближайшей и отдаленной (средне- и долгосрочной) перспективе. Так, по словам В.В. Путина, президента России, «ключевой риск - это долгосрочная безработица, пик которой при любом сценарии превысит уровень 2009 года», а динамика безработицы «станет и ключевым индикатором эффективности принимаемых нами антикризисных мер» [7].

\section{Выводы и предложения}

Во-первых, цифровизация национальной экономики осуществляется под воздействием различных факторов, как внутреннего, так и внешнего порядка. К последним, прежде всего, относится коронавирусная пандемия, криптовалютная экспансия, международные санкции и торговые войны.

Во-вторых, в условиях усиления внешних шоков для сохранения Россией своего государственного суверенитета правомочно и оправдано применение ручного режима управления и усиление государственного регулировании финансового рынка.

В-третьих, формирование в России мегарегулятора финансового рынка в лице Банка России и усиление полномочий Казначейства России в сфере финансовой экономики являются необходимыми организационными мерами в обеспечении финансовой безопасности Российской Федерации в условиях наблюдаемых внешних шоков: коронавирусной пандемии, криптовалютной экспансии, торговых воин и внешних санкций.

В-четвертых, принятая и реализуемая Банком России Концепция пропорционального регулирования и риск-ориентированного надзора деятельности финансовых организаций ориентирована на усиление централизации регулирования и концентрации капитала российского финансового рынка.

В-пятых, действия руководства России, его регионов, муниципальных образований, предприятий и организаций должны быть направлены на ускорение цифровизации российской экономики в русле обеспечения максимальной занятости россиян в ближайшей и отдаленной перспективе. 


\section{Список литературы}

1. Развитие пропорционального регулирования банковского сектора в Российской Федерации - Федеральный закон от 01.05.2017 № 92-Ф3 «О внесение изменений в отдельные законодательные акты Российской Федерации». - $\quad$ http://www.consultant.ru/document/cons_doc_LAW_216074/ (последняя дата обращения 25.04.2020).

2. Концепция пропорционального регулирования и рискориентированного надзора за НФО, Центральный банк РФ, Москва, 2018 https://www.cbr.ru/Content/Document/File/46871/PropNadz.pdf (последняя дата обращения 25.04.2020).

3. Taylor M. and Fleming A. Integrated Financial Supervision: Lessons of Scandinavian Experience // Finance \& Development. — 1999. — T. 36, № 4.

4. Masciandaro D. and Quintyn M. Regulating the Regulators: The Changing Face of Financial Supervision Architectures Before and After the Crisis // European Company Law. — 2011. — № 6. - P. 187-196.

5. Horáková M. and Glass E. Central Bank Directory 2017. - London: Central Banking Publishing, 2016.

6. Цакаев А.Х., Саидов 3.А. Механизм централизации регулирования и концентрации российского финансового рынка // Вестник ГГНТУ: гуманитарные и социально-экономические науки. Грозный. 2020, Том XYI № 1, C.15-24.

7. Путин на саммите G 20 предупредил о последствиях пандемии коронавируса - https//russian.rt.com/world/news/732153-putin-g20-posledstviyakoronovirus (последняя дата обращения 25.04.2020).

8. МВФ заявил о начале рецессии мировой экономики https//russian.rt.com/business/news/732525-mtf-mirovaya-economika (последняя дата обращения 25.04.2020).

9. В МВФ прогнозируют мировую рецессию в 2020 году https//russian.rt.com/business/731147-mvf-mirovaya-recessiya-koronavirus (последняя дата обращения 25.04.2020).

10. В ВО3 сообщили о более 1 млн. зараженных коронавирусом в мире https//russian.rt.com/business/734455-voz-koronavirus-zarazhenie (последняя дата обращения 25.04.2020).

11. Путин поручил компаниям РФ быстрее создать подразделения, работающие со стартапами - https://tass.ru/pmef-2017/articles/4307596 (последняя дата обращения 25.04.2020).

12. Ross Ulbricht, the Creator and Owner of Silk Road Website, Found Guilty in Manhattan Federal Court on All Counts. FBI.gov is an official site of the U.S. government, U.S. Department of Justice. February 5, 2015 [Электронный pecypc]. URL: https://www.fbi.gov/contact-us/field-offices/newyork/news/press-releases/ ross-ulbricht-the-creator-and-owner-of-the-silk-road-website-found-guity-inmanhattan-federal-court-on-all-counts (последняя дата обращения 25.04.2020). 
13. Самит «Группы двадцати», 26 марта 2020 г, 17.20, Московская область, Ново-Огарёво - http://kremlin.ru/events/president/news/63070 (последняя дата обращения 25.04.2020).

14. Официальный сайт Банка России. https://www.rbc.ru/crypto/news/ 5ea026009a7947010f1c358f?from=main_right (последняя дата обращения 25.04.2020).

15. Правительство купило Сбербанк у ЦБ https://www.vedomosti.ru/finance/articles/2020/04/10/827726-pravitelstvo-kupilosberbank (последняя дата обращения 25.04.2020). 